\title{
STUDY OF THE EFFECTIVENESS OF METHYLPREDNISOLONE AT DIFFERENT STAGES OF INPATIENT CARE FOR PATIENTS WITH PNEUMONIA CAUSED BY A NEW COVID-19 CORONAVIRUS INFECTION
}

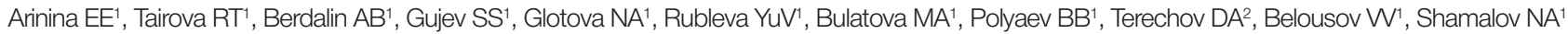

Federal Center for Brain and Neurotechnology of FMBA of Russia, Moscow, Russia

A.I. Burnazyan Federal Medical Biophysical Center of FMBA of Russia, Moscow, Russia

\begin{abstract}
Glucocorticoid therapy for a cytokine storm is one of the mainstays of managing the novel coronavirus disease COVID-19. The aim of this study was to evaluate the efficacy of methylprednisolone at different stages of medical care: in an intensive care unit (ICU) vs. a medical ward setting. Methylprednisolone therapy was delivered to 54 patients, amounting to $9 \%$ of the total patients hospitalized to the Federal Center of Brain Research and Neurotechnology of FMBA, Russia. Twenty-eight patients received methylprednisolone in the ICU setting; 26 patients, in a medical ward setting. The control group comprised 14 patients. Methylprednisolone was administered continuously, intravenously at $250 \mathrm{mg}$ per day over the course of 3 days; the total dose was $750 \mathrm{mg}$. The analysis revealed a significant reduction in mortality in the group receiving methylprednisolone in a medical ward setting (7.7\%) in comparison with the group receiving the drug in ICU (67.9\%) and the control group (42.9\%, $p<0.001)$. The need for mechanical ventilation was lower in the group receiving methylprednisolone in a medical ward (2 (7.7\%), 20 (71.4\%) and $7(50 \%)$ cases, respectively, $p<0.001)$. Thus, preventive anti-inflammatory methylprednisolone therapy for delivered in a medical ward setting reduces hospital mortality and the need for MV in patients with COVID-19-induced pneumonia.
\end{abstract}

Keywords: coronavirus infection, COVID-19, corticosteroids, viral pneumonia

$\triangle$ Correspondence should be addressed: Arinina EE

Received: 14.07.2020 Accepted: 03.08.2020 Published online: 17.08.2020

DOI: $10.47183 /$ mes.2020.009

\section{ИССЛЕДОВАНИЕ ЭФФЕКТИВНОСТИ МЕТИЛПРЕДНИЗОЛОНА НА РАЗНЫХ ЭТАПАХ ОКАЗАНИЯ СТАЦИОНАРНОЙ МЕДИЦИНСКОЙ ПОМОЩИ ПАЦИЕНТАМ С ПНЕВМОНИЕЙ, ВЫЗВАННОЙ НОВОЙ КОРОНАВИРУСНОЙ ИНФЕКЦИЕЙ COVID-19}

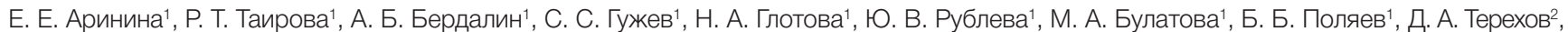
В. В. Белоусов ${ }^{1}$, Н. А. Шамалов ${ }^{1}$

Федеральный центр мозга и нейротехнологий, Федерального медико-биологического агентства, Москва, Россия

2 Федеральный медицинский биофизический центр имени А. И. Бурназяна ФМБА России, Москва, Россия

Одним из основных направлений терапии пневмонии, вызванной новой коронавирусной инфекцией COVID-19, является применение средств, направленных на борьбу с цитокиновым штормом, в том числе глюкокортикостероидов. Целью настоящего исследования явилось изучение эффективности применения метилпреднизолона на разных этапах оказания стационарной медицинской помощи - в условиях отделения реанимации и интенсивной терапии (ОРИТ) и в терапевтических отделениях (ТО). Терапия метилпреднизолоном была проведена 54 пациентам, что составило 9\% от общего количества госпитализированных больных в ФГБУ «ФЦМН» ФМБА России. В условиях ОРИТ терапия проводилась 28 пациентам, в условиях ТО - 26 больным, контрольную группу составили 14 пациентов. Метилпреднизолон вводили в суточной дозе 250 мг непрерывно внутривенно в течение трех суток, суммарная доза составила 750 мг. Результаты исследования показали достоверное уменьшение показателя летальности в группе, терапия метилпреднизолоном которым проводилась в ТО (7,7\%) по сравнению с группой, в которой терапия проводилась в ОРИТ (67,9\%) и контрольной группой (42,9\%, p < 0,001). Также для группы с проведенной терапией в ТО была характерна меньшая частота проведения ИВЛ (в 2 (7,7\%), 20 (71,4\%) и 7 (50\%) случаев, соответственно, $p<0,001)$. Таким образом, введение метилпреднизолона в условиях терапевтического отделения в качестве упреждающей противовоспалительной терапии способствует снижению показателей больничной летальности и частоты использования ИВЛ у пациентов с пневмонией, вызванной новой коронавирусной инфекцией COVID-19.

Ключевые слова: коронавирусная инфекция, COVID-19, глюкокортикостероиды, вирусная пневмония

Статья получена: 14.07.2020 Статья принята к печати: 03.08.2020 Опубликована онлайн: 17.08.2020

DOI: $10.47183 /$ mes.2020.009

The novel coronavirus SARS-CoV2 was first isolated and identified in Wuhan, China, in 2019. On March 11, 2020 WHO declared a pandemic of the novel coronavirus disease [1].

The excessive immune response to COVID-19 culminating in a cytokine release syndrome, also known as cytokine storm, plays the leading role in the pathogenesis of severe pneumonia caused by COVID-19. The devastating consequences of uncontrolled cytokine release include damage to the lungs, diffuse alveolar damage, acute respiratory distress syndrome (ARDS), and death [2-5].

So far, there is no effective etiotropic therapy against COVID-19. Improving oxygenation by prone positioning, oxygen therapy or mechanical ventilation, preventing and treating bacterial complications and using drugs to suppress the cytokine storm (glucocorticoids, inhibitors of proinflammatory factors and Janus-kinases) are the mainstay of anti-COVID-19 treatment [6-8].
Early reports on the benefits of glucocorticoid therapy in patients with COVID-19 were controversial [8-13]; however, later studies provided evidence of its efficacy $[14,15]$.

The aim of this study was to investigate the efficacy of methylprednisolone in reducing patient mortality in intensive care units (ICU) and medical wards.

\section{METHODS}

This study was a prospective quasi-experimental singlecenter open nonrandomized clinical trial. The study protocol was approved by the Academic Board of the Federal Center of Brain Research and Neurotechnology (FMBA, Russia) and the local Ethics Committee. The initial plan laid out in the first version of the protocol was that methylprednisolone would be administered only in an intensive care setting to eligible patients transferred to ICU from ER or a medical ward. Eligibility criteria 
for transfer to ICU are specified in the guidance of the Russian Ministry of Healthcare (ver. 5 and 6). [16, 17]. However, due to the increasing number of patients admitted to medical wards with signs of lung damage similar to those in patients already transferred to ICU, the protocol was revised. Importantly, patients on the hospital floor had similar comorbidities to patients already transferred to ICU. So, considering the first-hand experience in treating patients with COVID-19, amendments were proposed to the first version, and the Academic Board of the Federal Center of Brain Research and Neurotechnology revised the protocol. The second version of the protocol permitted administration of methylprednisolone via continuous 3-day IV infusions using Infusomat/Perfusor Space systems in a medical ward setting.

From April 13, 2020 to May 25, 2020, 603 patients with community-acquired COVID-19-induced pneumonia were hospitalized to the Federal Center of Brain Research and Neurotechnology. Methylprednisolone therapy was administered to 54 patients ( $9 \%$ of all hospitalized patients). Group 1 ( $n=28$ ) included patients receiving methylprednisolone therapy in the ICU setting only between April 24, 2020 and May 6 , 2020. Group $2(n=26)$ consisted of patients who received methylprednisolone in a medical ward setting between May 7 , 2020 and June 12, 2020. The historical control group (group 3, $n=14$ ) comprised patients hospitalized to the Federal Center of Brain Research and Neurotechnology from April 13, 2020 to April 23, 2020; these patients did not receive hormonal or other therapy for the cytokine storm (monoclonal antibodies, JAK inhibitors, etc.) and were comparable in terms of their clinical characteristics to the patients on methylprednisolone therapy.

The following inclusion criteria were applied:

1. Male and female patients aged over 18 years;

2. Positive PCR test results for SARS-CoV-2 RNA;

3. Clinical signs of pneumonia (fever $>38.5^{\circ} \mathrm{C}$, respiration rate over 22 breaths per min, shortness of breath on exertion, $\mathrm{SpO}_{2}<95 \%$ at room air);

4. Chest CT findings suggestive of pneumonia. Exclusion criteria:

1. Signs of bacterial or fungal infection confirmed by procalcitonin and/or presepsin test and full blood count;

2. HIV/AIDS;

3. Active or latent TB infection;

4. Congestive heart failure;

5. Recent myocardial infarction

6. Severely impaired liver and/or kidney function;

7. Recent intestinal anastomosis

8. Esophagitis, gastritis, active or latent peptic ulcer

9. Myasthenia gravis;

10. Glaucoma

11. Severe osteoporosis

12. Hypothyroidism

13. Psychiatric disorders

14. Poliomyelitis (except bulbar poliomyelitis and polioencephalitis)

15. BCG lymphadenitis;

16. Recent vaccination.

Continuous IV infusions of methylprednisolone (SoluMedrol; 250 mg per day) were administered to the patients over the course of 3 days; the total dose was $750 \mathrm{mg}$. The patients were monitored for blood pressure and glycemia; proton pump inhibitors were prescribed for gastric protection. The patients also received standard therapy for COVID-19 recommended by the guidance of the Russian Ministry of Healthcare (ver. 5 and 6): antibacterial and detoxicating agents, antipyretic drugs, and anticoagulants [16, 17]. Antimalarial and anti-HIV medications were not included in the regimen. Oxygen was delivered to patients with $\mathrm{SpO}_{2}<93 \%$ through nasal cannulas or a mask at $15 \mathrm{~L} / \mathrm{min}$.

IIIness severity was assessed on the NEWS scale [18]; lung damage was evaluated based on the chest CT scans following the guidance $[16,17]$. The efficacy of the administered therapy was determined based on the mortality rate; we also looked at the need for and duration of mechanical ventilation, the length of ICU and overall hospital stay. Body temperature dynamics were evaluated in groups 1 and 2 on days 3 and 5 after the beginning of methylprednisolone therapy; the respiration rate $(\mathrm{RR})$ and $\mathrm{SpO}_{2}$ were measured in group 1 and 2 patients who were not on MV. C-reactive protein (CRP) levels were measured to evaluate the severity of inflammation.

\section{Statistical analysis}

Categorical variables were compared using the chi square test; continuous variables were compared using the KruskalWallis test (differences between all groups) and the MannWhitney $U$ test (for groups 1 and 2). The Friedman test was applied to compare linked samples $\left(\mathrm{SpO}_{2}, \mathrm{RR}\right.$ and $\mathrm{CRP}$ before methylprednisolone therapy and on days 3 and 5 into therapy).To evaluate the effect of methylprednisolone on patient mortality adjusted for confounding factors (parameters that differed between the groups, including age, chronic heart failure, chronic renal failure, severity of lung damage on CT scans), binary logistic regression was applied. Quantitative variables are presented below as medians and upper and lower quartiles. All computations were performed in IBM SPSS ver. 16.0. The null hypothesis was rejected at $p<0.05$. Two-tailed tests were used in all cases.

\section{RESULTS}

The basic characteristics of the patients included in the study are provided in Table 1. All groups were comparable in terms of demographics (age, sex), time from disease onset to hospitalization, time from hospitalization to the initiation of methylprednisolone therapy (for groups 1 and 2).

The analysis of comorbidities revealed that group 1 was dominated by patients with chronic heart failure (CHF) and chronic kidney disease (CKD); these conditions were observed in 39.3\% $(p=0.009)$ and $25 \%(p=0.017)$ of patients, respectively. For other comorbidities, no significant differences were detected between the groups. Similarly, no significant differences were observed between the groups in terms of presenting symptoms: the majority of patients presented with cough, fever and labored breathing. The severity of pneumonia on the NEWS scale was comparable between all patient groups. However, there were significantly more patients with severe lung damage in group $1(p=0.012$ ). Thus, on admission the radiographic findings were indicative of a much more severe lung damage in group 1, which was also characterized by more frequent comorbidities, including $\mathrm{CHF}$ and $\mathrm{CKD}$.

In group 1, $2(7.1 \%)$ patients were transferred to ICU straight from ER; the remaining 26 patients were transferred from their medical wards to ICU due to disease progression, as recommended by the guidance $[16,17]$. In group 2 , only 2 patients $(7.7 \%)$ were transferred to ICU after methylprednisolone therapy and then placed on MV. In spite of intensive care, these 2 patients died. Eight (57.1\%) patients from group 3 were transferred from their medical wards to ICU and placed on MV; of them 6 (42.9\%) individuals died. 
Analysis of clinical outcomes (Table 2) revealed a significantly lower mortality rate in group 2 (2 (7.7\%) cases), as compared to groups 1 (19 (67.9\%) cases) and 3 (6 (42.9\%) cases, $p<0.001)$. In group 2, ME was less frequent than in groups 1 and 3 (2 (7.7\%), 20 $(71.4 \%)$ and 7 (50\%) patients, respectively, $p<0.001)$.

The longest ICU stay (median: 9 days) and the highest MV duration (median: 9 days) were observed in group 1 ( $p=0.025$ and $p=0.023$, respectively). In group 2, these parameters equaled 5 and 5 days, respectively, and in group 3, 5 and 3 days, respectively. No significant differences were detected between the groups in terms of total hospital stay.

Considering that our groups differed in a number of factors that could potentially affect the outcome (CHF, CKD, severity of lung damage on a CT scan, age - all presenting a pronounced trend, see Table 1), we applied binary regression in order to make adjustments for these confounding factors. Results are provided in Table 3.

Adjusted for confounding factors, the odds of death in group 2 were significantly lower than in 2 other groups. Notably, the contribution of age was substantial whereas the contribution of other predictors was insignificant. Perhaps, CHF and CKD are more prevalent and lung damage visible on CT is more severe in patients of advanced age, i.e. these parameters are not significant outside the context of age. The overall quality of

Table 1. Patient demographics our regression model was satisfactory: Nigel-Kirk's pseudo-Rsquared was 0.612, and the Hosmer-Lemeshow goodness of fit was 0.499 .

Comparative analysis of clinical and laboratory parameters between the groups of patients receiving methylprednisolone therapy in ICU vs. a medical ward setting is provided in Table 4. By day 5 after methylprednisolone therapy was initiated, group 2 was dominated by patients without hyperthermia (23 (92\%) cases), as compared to group 1 , where only 13 patients (50\%) $(p=0.002)$ had normal body temperature at this time point. Also, shortness of breath became less pronounced in group 2 on day 3 (end of methylprednisolone therapy): median RR was 19 breaths per min, whereas in group 1, RR was 24 breaths per min $(p=0.043)$. No significant differences in $\mathrm{SpO}_{2}$ were detected between the groups.

Prior to methylprednisolone therapy, CRP levels were high in both groups treated with this drug (median 136 [94; 213] mg/L in group 1 and 148 [68; 183] $\mathrm{mg} / \mathrm{L}$ in group 2). By day 3 into treatment, CRP levels started to decline, reaching 68 [41; 126] mg/L in group 1 and 52 [23; 142] mg/L in group 2 ; the differences between the groups were insignificant. On day 5 , CRP levels differed significantly between groups 1 and $2(68$ [35; 210] mg/L and 29 [12; 52] mg/L, respectively, $p=0.005)$.

\begin{tabular}{|c|c|c|c|c|c|}
\hline \multicolumn{2}{|c|}{ Parameter } & Group $1(n=28)$ & Group $2(n=26)$ & Group $3(n=14)$ & $\begin{array}{l}\text { Significance of } \\
\text { differences, } p\end{array}$ \\
\hline \multirow{2}{*}{ Sex } & Male (\%) & $17(60.7)$ & $17(65.4)$ & $12(85.7)$ & \multirow{2}{*}{0.251} \\
\hline & Female (\%) & $11(39.3)$ & $9(34.6)$ & $2(14.3)$ & \\
\hline \multicolumn{2}{|l|}{$\begin{array}{l}\text { Age, years } \\
\text { Median [Q1; Q3] }\end{array}$} & $66[58 ; 77]$ & $59[53 ; 70]$ & $57[49 ; 68]$ & 0.05 \\
\hline \multicolumn{2}{|c|}{$\begin{array}{l}\text { Time from disease onset to hospital admission, days } \\
\text { Median [Q1; Q3] }\end{array}$} & $7[5 ; 10]$ & $7[6 ; 9]$ & $8[3 ; 11]$ & 0.831 \\
\hline \multicolumn{2}{|c|}{$\begin{array}{l}\text { Time from hospital admission to beginning of } \\
\text { methylprednisolone therapy, days } \\
\text { Median [Q1; Q3] }\end{array}$} & $3[2 ; 5]$ & $3[2 ; 6]$ & - & 0.936 \\
\hline \multicolumn{6}{|c|}{ Comorbidities } \\
\hline \multicolumn{2}{|l|}{ Hypertension (\%) } & $18(64.3)$ & $12(46.2)$ & $8(57.1)$ & 0.405 \\
\hline \multicolumn{2}{|l|}{ Smoking (\%) } & $2(7.1)$ & $2(7.7)$ & $1(7.1)$ & 1.00 \\
\hline \multicolumn{2}{|l|}{ Diabetes mellitus (\%) } & $6(21.4)$ & $4(15.4)$ & $2(14.3)$ & 0.788 \\
\hline \multicolumn{2}{|c|}{ Past history of stroke or TIA (\%) } & $4(14.3)$ & $2(7.7)$ & $1(7.1)$ & 0.662 \\
\hline \multicolumn{2}{|c|}{ Past history of myocardial infarction (\%) } & $5(17.9)$ & $1(3.8)$ & $1(7.1)$ & 0.217 \\
\hline \multicolumn{2}{|l|}{ Obesity (\%) } & $9(32.1)$ & $4(15.4)$ & $4(28.6)$ & 0.180 \\
\hline \multicolumn{2}{|l|}{ Asthma (\%) } & $1(3.6)$ & $1(3.8)$ & 0 & 0.764 \\
\hline \multicolumn{2}{|c|}{ Chronic obstructive pulmonary disease (\%) } & $3(10.7)$ & $2(7.7)$ & 0 & 0.454 \\
\hline \multicolumn{2}{|c|}{ Chronic heart failure (\%) } & $11(39.3)$ & $4(15.4)$ & 0 & 0.009 \\
\hline \multicolumn{2}{|c|}{ Chronic kidney disease (\%) } & $7(25)$ & $1(3.8)$ & 0 & 0.017 \\
\hline \multicolumn{6}{|c|}{ Presenting complaints } \\
\hline \multicolumn{2}{|l|}{ Cough (\%) } & $26(96.3)$ & $24(92.3)$ & $14(100)$ & 0.516 \\
\hline \multicolumn{2}{|l|}{ Fever (\%) } & 27 (96.4) & $25(96.2)$ & $14(100)$ & 0.449 \\
\hline \multicolumn{2}{|c|}{ Shortness of breath $(\%)$} & $26(96.3)$ & $20(76.9)$ & $10(71.4)$ & 0.063 \\
\hline \multicolumn{6}{|c|}{ Severity on admission } \\
\hline \multicolumn{2}{|l|}{$\begin{array}{l}\text { NEWS score } \\
\text { Median [Q1; Q3] }\end{array}$} & $5[5 ; 7]$ & $4[2 ; 7]$ & $4[2 ; 6]$ & 0.173 \\
\hline \multirow{4}{*}{$\begin{array}{l}\text { Lung damage on } \mathrm{CT} \\
\text { on admission }\end{array}$} & Grade $1(\%)$ & $3(10.7)$ & $2(7.7)$ & $0(0)$ & \multirow{4}{*}{0.012} \\
\hline & Grade $2(\%)$ & $2(7.1)$ & $12(46.2)$ & $3(21.4)$ & \\
\hline & Grade $3(\%)$ & $11(39.3)$ & $10(38.5)$ & $7(50)$ & \\
\hline & Grade $4(\%)$ & $12(42.9)$ & $2(7.7)$ & $4(28.6)$ & \\
\hline
\end{tabular}


Intragroup comparisons of these parameters revealed that $\mathrm{CRP}(p=0.033), \mathrm{SpO}_{2}(p<0.0005)$ and $\mathrm{RR}(p<0.0005)$ dynamics were significant in group 1 . For group 1 , only CRP dynamics were significant $(p=0.023)$, unlike $\mathrm{RR}$ and $\mathrm{SpO}_{2}$.

\section{DISCUSSION}

This study investigated effects of methylprednisolone therapy at different stages of inpatient medical care. We found that administration of methylprednisolone in a medical ward setting aimed at preventing inflammation improves survival, reduces the frequency of patient transfer to ICU and the need for MV in patients with COVID-19-induced pneumonia. Methylprednisolone therapy delivered in the ICU setting did not have a significant effect on mortality (which was 67.9\%), in comparison with the control group, whereas its early application in a medical ward setting prevented most patients from worsening, transfer to ICU and placement on MV, resulting in lower mortality.

Being a potent anti-inflammatory drug, methylprednisolone can block secretion of proinflammatory cytokines and accelerate resolution of pulmonary and systemic inflammation in patients with pneumonia $[11,19]$. At the same time, some studies demonstrated that glucocorticoids hampered pathogen elimination from the organism and increased mortality in patients with other viral infections [11, 20]. However, there have been no studies so far addressing the use of the proposed methylprednisolone regimen against COVID-19.

There are a number of publications investigating the efficacy of glucocorticoid therapy in patients with COVID-19 progressed to pneumonia. Specifically, a retrospective cohort study conducted in patients with confirmed COVID-19 and ARDS revealed that methylprednisolone administered intravenously at $1-2 \mathrm{mg} / \mathrm{kg}$ per day for $5-7$ days reduced the risk of mortality (23 deaths in $50(46 \%)$ patients who received methylprednisolone vs. 21 deaths in 34 patients (61.8\%) who did not receive this drug) [21]. In another study conducted in 46 patients with severe COVID-19 progressed to respiratory failure, therapy with methylprednisolone was associated with better clinical benefits and reduced duration of the disease [22]. According to the Chinese Thoracic Society experts consensus, methylprednisolone should be administered at low to medium doses ( $\leq 0.5-1 \mathrm{mg} / \mathrm{kg}$ a day) [23]; it is reported that the most common methylprednisolone regimens in China are 40-80 mg of the drug per day for 3-6 days [24].

A study by Fadel Raef et al. [14] compared the effects of different methylprednisolone regimens in managing COVID-19: early (within 2 days after admission) vs. later (day 5 after admission therapy start. Methylprednisolone was delivered to patients at 0.5 to $1 \mathrm{mg} / \mathrm{kg}$ a day over the course of 3 days; the total daily dose was administered in two divided doses every $12 \mathrm{~h}$. The study demonstrated the efficacy of early methylprednisolone therapy in achieving a primary composite endpoint (death from any causes + transfer to ICU + placement on $\mathrm{ME}$ ). In the early therapy start group, the primary endpoint rate was $34.9 \%$, whereas in the later start group, it was 54.3\% $(p=0.005)$.

The methylprednisolone dosage and regimen used in our study differed from the cited studies: the drug was administered continuously at $250 \mathrm{mg}$ per day for 3 days in a row; this allowed us to use a higher total methylprednisolone dose (750 mg).

Our study has a few limitations. Due its quasi-experimental design, there was no randomization and placebo control; the control group was formed based on the historical principle. Patients from group 1 were slightly older, had more comorbidities and more severe damage to the lungs on CT scans.

Summing up, this study demonstrates the need for a randomized double-blind placebo-controlled trial of the efficacy of methylprednisolone therapy in patients with pneumonia caused by the novel coronavirus infection. In our experience, preventive methylprednisolone therapy might be beneficial in terms of costs incurred by a medical facility in the absence

Table 2. Comparative analysis of clinical outcomes and some clinical variables

\begin{tabular}{|l|c|c|c|c|}
\hline \multicolumn{1}{|c|}{ Parameter } & Group №1 $(n=28)$ & Group №2 $(n=26)$ & Group №3 $(n=14)$ & Significance of differences, $p$ \\
\hline Death (\%) & $19(67,9)$ & $2(7,7)$ & $6(42,9)$ & $<0,001$ \\
\hline ME (\%) & $20(71,4)$ & $2(7,7)$ & $7(50)$ & $<0,001$ \\
\hline $\begin{array}{l}\text { ME duration } \\
\text { Median [Q1; Q3] }\end{array}$ & $9[6 ; 13]$ & $5[2 ; 7]$ & $3[1 ; 5]$ & 0,023 \\
\hline $\begin{array}{l}\text { Days in ICU } \\
\text { Median [Q1; Q3] }\end{array}$ & $9[6 ; 17]$ & $5[2 ; 7]$ & $5[2 ; 6]$ & 0,025 \\
\hline $\begin{array}{l}\text { Total length of stay } \\
\text { Median [Q1; Q3] }\end{array}$ & $19[12 ; 25]$ & $16[12 ; 19]$ & $14[6 ; 17]$ & 0,074 \\
\hline
\end{tabular}

Table 3. Binary logistic regression with confounding factors and a group factor, death is dependent variable. Cl- confidence interval, OR- odds ratio. Significant predictors are highlighted. OR is not specified for the reference category in the case of categorial predictors

\begin{tabular}{|l|c|c|c|c|}
\hline \multirow{2}{*}{ Predictor } & Significance $(p)$ & \multirow{2}{*}{ OR } & \multicolumn{2}{c|}{ 95\% Cl for OR } \\
\cline { 3 - 5 } & & & & Upper limit \\
\hline Group 2 & 0.003 & 52.693 & 4.065 & 683.107 \\
\hline Group 3 & 0.002 & 47.824 & 4.690 & 487.640 \\
\hline Group 1 & 0.001 & 0.202 & 0.021 & 1.929 \\
\hline CHF & 0.165 & 6.191 & 0.549 & 69.790 \\
\hline CKD & 0.140 & & & 9.323 \\
\hline Lung damage grade 1 & 0.654 & 0.306 & 0.010 & 4.885 \\
\hline Lung damage grade 2 & 0.497 & 0.191 & 0.007 & 12.088 \\
\hline Lung damage grade 3 & 0.317 & 0.434 & 0.016 & 1.194 \\
\hline Lung damage grade 4 & 0.623 & 1.104 & 1.021 & \\
\hline Age & 0.014 & & & \\
\hline
\end{tabular}


Table 4. Comparative analysis of clinical and laboratory data between groups 1 and 2

\begin{tabular}{|l|c|c|c|}
\hline \multicolumn{1}{|c|}{ Parameter } & Group №1 $(n=28)$ & Group №2 $(n=26)$ & Significance of differences, $p$ \\
\hline $\begin{array}{l}\text { Body temperature recovery on day 3 } \\
\text { from therapy onset (\%) }\end{array}$ & $14(51.9)$ & 19 (73.1) & 0.158 \\
\hline $\begin{array}{l}\text { Body temperature recovery on day 5 } \\
\text { from therapy onset (\%) }\end{array}$ & $13(50)$ & 23 (92) & 0.002 \\
\hline $\begin{array}{l}\text { RR before therapy } \\
\text { Median [Q1; Q3] }\end{array}$ & $24[20 ; 28]$ & $24[22 ; 27]$ & 0.754 \\
\hline $\begin{array}{l}\text { RR on day 3 from therapy onset } \\
\text { Median [Q1; Q3] }\end{array}$ & $24[20 ; 25]$ & $19[18 ; 20]$ & 0.043 \\
\hline $\begin{array}{l}\text { RR on day 5 from therapy onset } \\
\text { Median [Q1; Q3] }\end{array}$ & $20[18 ; 30]$ & $19[18 ; 20]$ & 0.117 \\
\hline $\begin{array}{l}\text { SpO before therapy, } \% \\
\text { Median [Q1; Q3] }\end{array}$ & $90[87 ; 94]$ & $93[90 ; 95]$ & 0.340 \\
\hline $\begin{array}{l}\text { SpO on day 3 from therapy onset, \% } \\
\text { Median [Q1; Q3] }\end{array}$ & $94[89 ; 98]$ & $95[95 ; 97]$ & 0.170 \\
\hline $\begin{array}{l}\text { SpO2 on day 5 from therapy onset, \% } \\
\text { Median [Q1; Q3] }\end{array}$ & $96[84 ; 96]$ & $97[96 ; 98]$ & 0.163 \\
\hline $\begin{array}{l}\text { CRP before therapy } \\
\text { Median [Q1; Q3] }\end{array}$ & $136[94 ; 213]$ & $148[68 ; 183]$ & 0.436 \\
\hline $\begin{array}{l}\text { CRP on day 3 from therapy onset } \\
\text { Median [Q1; Q3] }\end{array}$ & $68[41 ; 126]$ & $52[23 ; 142]$ & 0.307 \\
\hline $\begin{array}{l}\text { CRP on day 5 from therapy onset } \\
\text { Median [Q1; Q3] }\end{array}$ & $68[35 ; 210]$ & $29[12 ; 52]$ & 0.005 \\
\hline
\end{tabular}

of sufficient funding. The obtained data can be used in further studies looking into the effect of different therapeutic
anti-COVID-19 regimens on public health budget at many levels.

\section{References}

1. https://www.who.int/ru/dg/speeches/detail/who-directorgeneral-s-opening-remarks-at-the-media-briefing-on-covid-19--11-march-2020

2. Huang, C., Wang, Y., Li, X., et al. Clinical features of patients infected with 2019 novel coronavirus in Wuhan, China // The Lancet, 2020, Feb. 15; 395(10223): pp. 497-506. doi: 10.1016/ S0140-6736(20)30183-5.

3. Tian, S., Hu, W., Niu, L., et al. Pulmonary pathology of early phase 2019 novel coronavirus (COVID-19) pneumonia in two patients with lung cancer // J Thorac Oncol, 2020, Feb. 28. pii: S15560864(20)30132-5. doi: 10.1016/j.jtho.2020.02.010.

4. Xu, Z., Shi, L., Wang, Y., et al. Pathological findings of COVID-19 associated with acute respiratory distress syndrome // Lancet Respir Med, 2020, Feb. 18, pii: S2213-2600(20)30076-X. doi: 10.1016/S2213-2600(20)30076-X.

5. Zhou, Y., Fu, B., Zhang, $X$, et al. Pathogenic $T$ cells and inflammatory monocytes incite inflammatory storm in Severe COVID-19 patients // National Science Review, nwaa041, https:// doi.org/10.1093/nsr/nwaa041.

6. Centers for Disease Control and Prevention. Coronavirus disease 2019 (COVID-19): cases and latest updates. Accessed: April 7, 2020 (https://www.cdc.gov/coronavirus/2019-ncov/casesupdates/cases-in-us.html)

7. Siddiqi, H.K., Mehra, M.R. COVID-19 Illness in Native and Immunosuppressed States: A Clinical-Therapeutic Staging Proposal // The Journal of Heart and Lung Transplantation, 2020, Mar. 20. https://doi.org/10.1016/j.healun.2020.03.012

8. McCreary, E.K., Pouge, J.M. COVID-19 Treatment: A Review of Early and Emerging Options / Open Forum Infectious Diseases, 2020. ofaa105. https://doi.org/10.1093/ofid/ofaa105

9. Guan, W.J., Ni, Z.Y., Hu, Y, et al. Clinical Characteristics of Coronavirus Disease 2019 in China // N Engl J Med, 2020, Feb. 28. doi: 10.1056/NEJMoa2002032.

10. Zhang, W., Zhao, Y., Zhang, F., et al. The use of anti-inflammatory drugs in the treatment of people with severe coronavirus disease 2019 (COVID-19): The experience of clinical immunologists from China // Clinical Immunology, 2020, Mar. 25:108393
11. Russell, C.D., Millar, J.E., Baillie, J.K. Clinical evidence does not support corticosteroid treatment for 2019-nCoV lung injury // Lancet. 2020; 395(10223):473-5. https://doi.org/10.1016/ S0140-6736(20)30317-2

12. Wang, D., Hu, B., Hu, C., et al. Clinical Characteristics of 138 Hospitalized Patients with 2019 Novel Coronavirus-Infected Pneumonia in Wuhan, China // JAMA, 2020, Feb. 7. doi: 10.1001/ jama.2020.1585

13. Yang, X., Yu, Y., Xu, J., et al. Clinical course and outcomes of critically ill patients with SARS-CoV-2 pneumonia in Wuhan, China: a single-centered, retrospective, observational study // Lancet Respir Med, 2020, Feb. 24. pii: S2213-2600(20)30079-5.

14. Raef Fadel, D.O, Austin R Morrison, Pharm.D, Amit Vahia, M.D, Zachary R Smith, Pharm.D, Zohra Chaudhry, M.D, Pallavi Bhargava, M.D, Joseph Miller, M.D, Rachel M Kenney, Pharm.D, George Alangaden, M.D, Mayur S Ramesh, M.D, Henry Ford COVID-19 Management Task Force, Early Short Course Corticosteroids in Hospitalized Patients with COVID-19 // Clinical Infectious Diseases. ciaa601

15. Peter Horby, Wei Shen Lim, Jonathan Emberson, Marion Mafham, Jennifer Bell, Louise Linsell, Natalie Staplin, Christopher Brightling, Andrew Ustianowski, Einas Elmahi, Benjamin Prudon, Christopher Green, Timothy Felton, David Chadwick, Kanchan Rege, Christopher Fegan, Lucy C Chappell, Saul N Faust, Thomas Jaki, Katie Jeffery, Alan Montgomery, Kathryn Rowan, Edmund Juszczak, J Kenneth Baillie, Richard Haynes, Martin J Landray. Effect of Dexamethasone in Hospitalized Patients with COVID-19: Preliminary Report., RECOVERY Collaborative Group medRxiv 2020.06.22.20137273; doi: https://doi.org/10.1101/20 20.06.22.20137273

16. https://static 2.rosminzdrav.ru/system/attachments/ attaches/000/049/949/original/\%D0\%92\%D1\%80\%D0\%B5\%D 0\%BC\%D0\%B5\%D0\%BD\%D0\%BD\%D1\%8B\%D0\%B5 \%D0\% 9C\%D0\%A0 COVID-19 \%D0\%B2\%D0\%B5\%D1\%80\%D1\%81 \%D0\%B8\%D1\%8F_5.pdf

17. https://static-1.rosminzdrav.ru/system/attachments/ attaches/000/050/122/original/28042020_\%D0\%9CR_ 
COVID-19_v6.pdf

18. Royal College of Physicians. National Early Warning Score (NEWS): Standardising the assessment of acuteillness severity in the NHS. Report of a working party. London: RCP, 2012.

19. Villar, J., Belda, J., Anon, J.M., Blanco, J., Perez-Mendez, L., Ferrando, C., et al. Evaluating the efficacy of dexamethasone in the treatment of patients with persistent acute respiratory distress syndrome: study protocol for a randomized controlled trial. Trials. 2016;17: 342. https://doi.org/10.1186/s13063-016-1456-4.

20. Arabi, Y.M., Mandourah, Y., Al-Hameed, F., et al. Corticosteroid Therapy for Critically III Patients with Middle East Respiratory Syndrome // Am J Respir Crit Care Med, 2018, Mar. 15,197(6), pp. 757-767.

21. Wu, C., Chen, X., Cai, Y., Xia, J., Zhou, X., Xu, S., et al. Risk factors associated with acute respiratory distress syndrome and death in patients with coronavirus disease 2019 pneumonia in Wuhan, China // JAMA Intern Med, 2020. https://doi.org/10.1001/ jamainternmed.2020.0994.

22. Wang,Y., Jiang, W., He, Q., Wang, C., Wang, B., Zhou, P., et al. Early, low-dose and short-term application of corticosteroid treatment in patients with severe COVID-19 pneumonia: single-center experience from Wuhan, China // medRxiv. 2020:2020.03.06.20032342. https://doi.org/10.1101/2020.03.0 6.20032342

23. Shang, L., Zhao, J., Hu, Y., Du, R., Cao B. On the use of corticosteroids for 2019-nCoV pneumonia // Lancet, 2020;395(10225):683-4. https://doi.org/10.1016/S01406736(20)30361-5.

24. J F. Internet Book of Critical Care. From EMCrit Project website. 2020, Apr. 7. doi:https://emcrit.org/ibcc/COVID19/.

\section{Литература}

1. https://www.who.int/ru/dg/speeches/detail/who-directorgeneral-s-opening-remarks-at-the-media-briefing-on-covid-19--11-march-2020

2. Huang, C., Wang, Y., Li, X., et al. Clinical features of patients infected with 2019 novel coronavirus in Wuhan, China // The Lancet, 2020, Feb. 15; 395(10223): pp. 497-506. doi: 10.1016/ S0140-6736(20)30183-5.

3. Tian, S., Hu, W., Niu, L., et al. Pulmonary pathology of early phase 2019 novel coronavirus (COVID-19) pneumonia in two patients with lung cancer // J Thorac Oncol, 2020, Feb. 28. pii: S15560864(20)30132-5. doi: 10.1016/j.jtho.2020.02.010.

4. Xu, Z., Shi, L., Wang, Y., et al. Pathological findings of COVID-19 associated with acute respiratory distress syndrome // Lance Respir Med, 2020, Feb. 18, pii: S2213-2600(20)30076-X. doi: 10.1016/S2213-2600(20)30076-X.

5. Zhou, Y., Fu, B., Zhang, X., et al. Pathogenic T cells and inflammatory monocytes incite inflammatory storm in Severe COVID-19 patients // National Science Review, nwaa041, https:// doi.org/10.1093/nsr/nwaa041.

6. Centers for Disease Control and Prevention. Coronavirus disease 2019 (COVID-19): cases and latest updates. Accessed: April 7, 2020 (https://www.cdc.gov/coronavirus/2019-ncov/casesupdates/cases-in-us.html)

7. Siddiqi, H.K., Mehra, M.R. COVID-19 Illness in Native and Immunosuppressed States: A Clinical-Therapeutic Staging Proposal // The Journal of Heart and Lung Transplantation, 2020, Mar. 20. https://doi.org/10.1016/j.healun.2020.03.012

8. McCreary, E.K., Pouge, J.M. COVID-19 Treatment: A Review of Early and Emerging Options / Open Forum Infectious Diseases, 2020. ofaa105. https://doi.org/10.1093/ofid/ofaa105

9. Guan, W.J., Ni, Z.Y., Hu, Y., et al. Clinical Characteristics of Coronavirus Disease 2019 in China // N Engl J Med, 2020, Feb. 28. doi: 10.1056/NEJMoa2002032.

10. Zhang, W., Zhao, Y., Zhang, F., et al. The use of anti-inflammatory drugs in the treatment of people with severe coronavirus disease 2019 (COVID-19): The experience of clinical immunologists from China // Clinical Immunology, 2020, Mar. 25:108393

11. Russell, C.D., Millar, J.E., Baillie, J.K. Clinical evidence does not support corticosteroid treatment for 2019-nCoV lung injury // Lancet. 2020; 395(10223):473-5. https://doi.org/10.1016/ S0140-6736(20)30317-2.

12. Wang, D., Hu, B., Hu, C., et al. Clinical Characteristics of 138 Hospitalized Patients with 2019 Novel Coronavirus-Infected Pneumonia in Wuhan, China // JAMA, 2020, Feb. 7. doi: 10.1001/ jama.2020.1585.

13. Yang, X., Yu, Y., Xu, J., et al. Clinical course and outcomes of critically ill patients with SARS-CoV-2 pneumonia in Wuhan, China: a single-centered, retrospective, observational study // Lancet Respir Med, 2020, Feb. 24. pii: S2213-2600(20)30079-5.

14. Raef Fadel, D.O, Austin R Morrison, Pharm.D, Amit Vahia, M.D, Zachary R Smith, Pharm.D, Zohra Chaudhry, M.D, Pallavi Bhargava, M.D, Joseph Miller, M.D, Rachel M Kenney, Pharm.D,

George Alangaden, M.D, Mayur S Ramesh, M.D, Henry Ford COVID-19 Management Task Force, Early Short Course Corticosteroids in Hospitalized Patients with COVID-19 // Clinical Infectious Diseases. ciaa601

15. Peter Horby, Wei Shen Lim, Jonathan Emberson, Marion Mafham, Jennifer Bell, Louise Linsell, Natalie Staplin, Christopher Brightling, Andrew Ustianowski, Einas Elmahi, Benjamin Prudon, Christopher Green, Timothy Felton, David Chadwick, Kanchan Rege, Christopher Fegan, Lucy C Chappell, Saul N Faust, Thomas Jaki, Katie Jeffery, Alan Montgomery, Kathryn Rowan, Edmund Juszczak, J Kenneth Baillie, Richard Haynes, Martin J Landray. Effect of Dexamethasone in Hospitalized Patients with COVID-19: Preliminary Report., RECOVERY Collaborative Group medRxiv 2020.06.22.20137273; doi: https://doi.org/10.1101/20 20.06.22.20137273

16. https://static 2.rosminzdrav.ru/system/attachments/ attaches/000/049/949/original/\%D0\%92\%D1\%80\%D0\%B5\%D 0\%BC\%D0\%B5\%D0\%BD\%D0\%BD\%D1\%8B\%D0\%B5 \%D0\% 9C\%D0\%AO_COVID-19_\%D0\%B2\%D0\%B5\%D1\%80\%D1\%81 \%D0\%B8\%D1\%8F 5.pdf

17. https://static-1.rosminzdrav.ru/system/attachments/ attaches/000/050/122/original/28042020_\%D0\%9CR_ COVID-19_v6.pdf

18. Royal College of Physicians. National Early Warning Score (NEWS): Standardising the assessment of acuteillness severity in the NHS. Report of a working party. London: RCP, 2012.

19. Villar, J., Belda, J., Anon, J.M., Blanco, J., Perez-Mendez, L., Ferrando, C., et al. Evaluating the efficacy of dexamethasone in the treatment of patients with persistent acute respiratory distress syndrome: study protocol for a randomized controlled trial. Trials. 2016;17: 342. https://doi.org/10.1186/s13063-016-1456-4.

20. Arabi, Y.M., Mandourah, Y., Al-Hameed, F., et al. Corticosteroid Therapy for Critically III Patients with Middle East Respiratory Syndrome // Am J Respir Crit Care Med, 2018, Mar. 15,197(6), pp. 757-767.

21. Wu, C., Chen, X., Cai, Y., Xia, J., Zhou, X., Xu, S., et al. Risk factors associated with acute respiratory distress syndrome and death in patients with coronavirus disease 2019 pneumonia in Wuhan, China // JAMA Intern Med, 2020. https://doi.org/10.1001/ jamainternmed.2020.0994.

22. Wang,Y., Jiang, W., He, Q., Wang, C., Wang, B., Zhou, P., et al. Early, low-dose and short-term application of corticosteroid treatment in patients with severe COVID-19 pneumonia: single-center experience from Wuhan, China // medRxiv. 2020:2020.03.06.20032342. https://doi.org/10.1101/2020.03.0 6.20032342

23. Shang, L., Zhao, J., Hu, Y., Du, R., Cao B. On the use of corticosteroids for 2019-nCoV pneumonia // Lancet, 2020;395(10225):683-4. https://doi.org/10.1016/S01406736(20)30361-5.

24. J F. Internet Book of Critical Care. From EMCrit Project website. 2020, Apr. 7. doi:https://emcrit.org/ibcc/COVID19/. 